\title{
"The speed of the political is not that of the scientific": on the time of development in an agricultural technology transfer program
}

\author{
Vanessa Parreira Perin ${ }^{1}$ \\ 'Universidade Federal do Rio de Janeiro, Programa de Pós-Graduação em Sociologia e Antropologia, \\ Rio de Janeiro/RJ, Brasil
}

\begin{abstract}
In this article I seek to present certain problematics related to the ProSAVANA agricultural development program, highlighting a mismatch between a political sphere and a scientific sphere, which allowed me to reflect on some effects of the technical discourse that has guided the implementation of this international cooperation project. From research that sought to do an ethnography on the operationalization of this program, I intend to present the manner in which such technopolitical breakdowns in the proposed "technologies transfer" have produced a composition of different temporalities, which conferred a particular pace to the effectiveness of ProSAVANA. In order to describe this strange relation between different forms of knowledge that are expressed in the time of accomplishing a development project - unfolding at different speeds -, I follow the idea of Mbembe (2011) that in the postcolony, time is constantly emerging. In this sense, throughout this article I seek to describe how, by decomposing these different speeds, it is possible to understand the temporalities that emerge from the particular entanglement of technopolitical relations that confer the materiality of this development project.
\end{abstract}

Key words: development; technopolitics; temporality; international cooperation. 


\section{"A velocidade do político não é a do científico":}

\section{sobre o tempo do desenvolvimento em um programa de transferência de tecnologia agrícola}

\section{Resumo}

Neste artigo procuro apresentar algumas problemáticas relacionadas ao programa de desenvolvimento agrícola ProSavana, destacando um descompasso entre um âmbito político e outro científico, que me permitiu refletir sobre alguns efeitos do discurso técnico que tem orientado a implementação desse empreendimento de cooperação internacional. A partir de uma pesquisa que procurou etnografar a operacionalização deste programa, pretendo apresentar a maneira como tais descompassos tecnopolíticos na "transferência de tecnologias" proposta, têm produzido uma composição de diferentes temporalidades, que conferiram um andamento particular à efetivação do ProSavana. Para tentar descrever essa estranha relação entre diferentes formas de saber que se expressam no tempo de realização um projeto de desenvolvimento - desenrolado em diferentes velocidades - parto da ideia de Mbembe (2011) de que na pós-colônia o tempo se dá de forma emergente. Nesse sentido, ao longo deste artigo buscarei descrever como, decompostas estas diferentes velocidades seria possível compreender as temporalidades que emergem do entanglement particular de relações tecnopolíticas que conferem a materialidade desse projeto de desenvolvimento.

Palavras-chave: desenvolvimento; tecnopolítica; temporalidade; cooperação internacional. 


\section{"The speed of the political is not that of the scientific": on the time of development in an agricultural technology transfer program'}

Vanessa Parreira Perin

The ProSAVANA program is a triangular cooperation proposal signed between the governments of Japan, Brazil and Mozambique, which has sought to execute technical projects for agricultural development in the northern region of this African country. In order to conduct a Brazilian "technology transfer" to the area known as the Nacala Corridor, the main reference for its elaboration was the experience acquired from the Brazilian and Japanese Cooperation Program for the Agricultural Development of the Cerrado (Programa de Cooperação Brasileira e Japonesa para o Desenvolvimento Agrícola do Cerrado, PRODECER), a Japanese-Brazilian initiative responsible for the institutionalization of a highly technified and mechanized agricultural production model currently in force in the Brazilian Cerrado region. The agricultural technology that was proposed to transfer to Mozambique, therefore, is largely the result of the experience of "conservative modernization" (Delgado 2012) of the Brazilian rural environment, fostered from the mid-7os of the last century.

In February 2018, I paid a visit to the Soil Analysis Laboratory of Nampula, a city in the northern region of Mozambique. I had marked an appointment to converse with its director to learn more about the laboratory's work, since it crystallized the "technology transfer" imparted within the scope of ProSAVANA, one of the objects of research that I was conducting at that time. I was accompanied by a fellow sociologist who was also conducting an investigation on the same program and, therefore, we decided to perform that stage of fieldwork together. The director met us amenably at the entrance of the laboratory that was inside the broader facilities of the Mozambique Institute of Agricultural Research (Instituto de Investigação Agrária de Moçambique, IIAM), while we continued under the hot sun of Nampula at that time of year.

We went to his office and he initially commented that he was very pleased to receive researchers from an area of social research. According to the director, things were not going well there and it would be up to us to understand and explain what had gone wrong. If everything remained as it was, the laboratory would not continue to function for much longer. The funds that maintained it until then came from Japanese cooperation and with the end of the program component that included the construction of the laboratory, among other activities, it was the responsibility of the Mozambican government to keep it running. Considering the very low government investments regarding the country's agricultural sector, ${ }^{2}$ this was unlikely to happen.

\footnotetext{
This article forms part of my doctoral research, which was supported by the Wenner Gren Foundation (Dissertation Fieldwork Grant) to conduct field research in Mozambique.

2 Despite being presented by the Mozambican government as the basis of the economy, since approximately $75 \%$ of the population lives in rural areas and agriculture is their main source of income, the agricultural sector has historically received little public investment. According to Mosca (2012), with the exception of the early post-independence years, agriculture was not privileged by the state and, beyond the stagnation or setback of many elements of agrarian development, there were no structural transformations in the productive base, technologies, or productivity, contrary to the official discourse on the sector.
} 
The researcher attributed many of the problems faced to the difficulty in dealing with "the Japanese," who he described as very closed in their own way of doing things, with no possibility of dialogue. They built a laboratory that was unsustainable for Mozambican reality. He pointed to the ceiling where it was possible to observe several empty lamp holders, even though the room was very bright. "Do you understand what I'm saying? Do you think we need so many lamps in a country with so much sunlight?" he commented. He also recalled how this was incompatible with the recurring energy spikes and outages in Nampula. It was not uncommon for us to go a few hours without electricity in much of the city. However, Japanese cooperation always followed the same installation pattern in their laboratories, which had to be repeated in any place where their technicians were to work, in order to maintain the same quality of work environment.

His complaint extended to the machines that were purchased. "A donation from the Japanese people," printed on the stickers present on all types of material acquired through cooperation with this country, whether it was a pen, a centrifuge, or a huge crane in the port of the city of Nacala. State-of-the-art technology, that was already deteriorating due to such power outages. And if a piece broke, explained the director, a technician from South Africa had to come to repair it, since there were no technicians qualified for such work in Mozambique. And if the piece needed to be exchanged, it would certainly have to be imported, since the country did not produce them. An expense that the laboratory was unable to constantly meet. In addition, there was a loss as a result of the import waiting time. Therefore, the technology brought in proved to be unsustainable for Mozambican financial and management capacity. Although well equipped, "the country cannot handle" the expenses generated by the laboratory's activities, explained the Mozambican researcher.

He was visibly discouraged by the situation he faced. He told us that he had worked on the elaboration of ProSAVANA from the beginning, from the first meetings in Brazil. It was supposed to be a project implemented in southern Mozambique, where his capital is located, but he affirmed that he understood the Cerrado, since he had graduated in Brazil. Therefore, he put pressure on the cooperants to install the project in the north of the country, where the existing soils are closer to those of the Brazilian Cerrado, our "Savanna." The initial idea of conducting the program in the south came from the fact that those with power in Mozambique were there. Politicians who, as I was told by several interlocutors throughout the research, had already "parceled out" all the land among themselves. When visiting the Cerrado and glimpsing our huge soy farms, said the director, these politicians wanted that type of enterprise to take place in Mozambique and quickly. Except that "the speed of the political is not that of the scientific," he said. In his opinion, this had created a large portion of the problems in the implementation of the program.

I highlight this mismatch between a political sphere and a scientific sphere, addressed in the director's narrative regarding the laboratory constructed by international cooperation, as it allows reflection on some effects of the technical discourse that guides the implementation of ProSAVANA, which I seek to discuss throughout this article. Based on research that sought to do an ethnography on the implementation of this program, I intend to present the manner in which the techno-political ${ }^{3}$ mismatches that involve this undertaking of "technology transfer" for development have produced a composition of different temporalities, which conferred a particular pace to the operationalization of this program.

\footnotetext{
3 According to Mitchell (2002), "Techno-politics is always a technical body, an alloy that must emerge from a process of manufacture whose ingredients are both human and nonhuman, both intentional and not, and in which the intentional or the human is always somewhat overrun by the unintended. But it is a particular form of manufacturing, a certain way of organizing the amalgam of human and nonhuman, things and ideas, so that the human, the intellectual, the realm of intentions and ideas seems to come first and to control and organize the nonhuman" (p.42-43)
} 
Based on the repositioning of a problematic described as technical in the field of politics, by organizations and social movements, by peasants and by the technicians themselves, this work also questions how to analytically surpass the anti-political machine of the development apparatus (Ferguson 1994) and its mechanisms of rendering technical (Li 2007). ${ }^{4}$ Therefore, I emphasize the inseparable presence of politics in the choice and use of various techniques, considering that these do not constitute a set of procedures whose objective ends are self-contained (Ribeiro 2018). In this sense, I sought to do an ethnography on the ways in which "the technique appears in the world as inseparable from politics, either as intertwined domains or practices, or as domains or practices considered separate, but in both cases in close relationship" (Moraswka Vianna \& Ribeiro 2018: 10). The speed of the scientific (or technical) and the political are not the same, as the director of the laboratory in Nampula pointed out, but they are placed in a specific and situated relationship.

As Gupta (1998) indicates, in order to understand why certain agricultural policies have been promoted, how they are implemented and why they are adopted or challenged by farmers, it is important to keep in mind three different frameworks: the discourse of development and its modernization strategies; a change in the nature of global capitalism; the technological transformations promoted by the green revolution. Each of these "macrologies" brings a different temporality, creating both moments of overlap and disjuncture and intersections.

Contestations of the state's claims of fostering "development" reveal that the postcolonial condition is distinguished by heterogeneous temporalities that mingle and jostle with one another to interrupt the teleological narratives that have served both to constitute and stabilize the identity of the "West" (Gupta 1998: 17).

And in order to describe this strange relationship between different forms of knowledge that are expressed in the time of accomplishing a development project -unfolding at different speeds -, I follow the idea of Mbembe (2001) that in the postcolony, time is constantly emerging. According to the author, the peculiarity of historicity in African societies is rooted in a multiplicity of times, trajectories, rationalities that, although they are private or local on some scale, cannot fail to be conceptualized in a globalized world and in a time on the move. The postcolonial debate in the African context, therefore, implies not only a denunciation of power, but a discussion about time and displacement, which rehabilitates notions of age and durée when thinking about the African experience.

By age is meant not a simple category of time but a number of relationships and a configuration of events - often visible and perceptible, sometimes diffuse, "hydra-headed," but to which contemporaries could testify since very aware of them. As an age, the postcolony encloses multiple durées made up of discontinuities, reversals, inertias, and swings that overlay one another, interpenetrate one another, and envelope one another: an entanglement (Mbembe 2001: 14).

\footnotetext{
4 A striking feature of development projects highlighted by Ferguson (1994) is that they almost ceaselessly fail to achieve their apparent goals. However, the productive character of these interventions is not in what they do not do, or in what they should do, but in what they actually create with their intervention, beyond what the technicians understand as failure. In the case observed by the author in Lesoto, results that at first appeared as mere side effects of an unsuccessful attempt to project an economic transformation became readable from another perspective, as instrumental elements that extended the exercise of state bureaucracy in that country. At the same time, a mechanism for depoliticizing poverty was created: an anti-political machine that repeatedly replenished questions about the distribution of land, resources, labor and wages as technical problems that could be solved with the correct intervention of the development apparatus. $\mathrm{Li}$ (2007) also calls attention to an inevitable gap between what is intended and what is accomplished by these models. Thus, her analysis turns to the will to improve of development programs, a mechanism situated in government practices described by Foucault, that is, interventions that seek to direct the conduct of the subjects in a calculated manner. Such interventions are elaborated, first, by problematizing certain phenomena, identifying deficiencies that need to be rectified. Then, through a set of practices that the author calls rendering technical, where the objective is to represent the domain to be governed as an intelligible field, with defined characteristics and limits, on which certain techniques can act.

5 According to the author, shortly after the Second World War, when the end of colonial government seemed inevitable, the development apparatus institutionalized a new form of governmentality, in which the new independent nations of the third world were located in particular times and spaces. When using the term "post-colonial condition," therefore, Gupta refers to a set of locations articulated by the historical trajectory of colonialism, development and global capitalism.
} 
Thus, in this emerging time that combines many temporalities, demarcating a before and one after colonization is not enough to exhaust the questions concerning the passage of stages, for example, as the discourse of development does. ${ }^{6}$ Mbembe highlights that it is necessary to know not only how this multiplicity of times are rewritten in a historical durée, but also in native durées and in the particularity of this time that is constantly emerging:

To think relevantly about this time that is appearing, this passing time, meant abandoning conventional views, for these only perceive time as a current that carries individuals and societies from a background to a foreground, with the future emerging necessarily from the past and following that past, itself irreversible. But of central interest was that peculiar time that might be called the time of existence and experience, the time of entanglement. (Mbembe 2001: 15)

It is in this sense that throughout this article I try to describe how, by decomposing the different speeds implicated in the implementation of the ProSAVANA program, it is possible to understand the temporalities that emerge from the particular entanglement of techno-political relations that confer the materiality of this development project.

\section{Technology transfer between parallels}

ProSAVANA is part of the Brazilian foreign policy framework of the Lula government (2003-10), which highlighted South-South cooperation as one of the priorities of its international policy. With a strong presence in the Food and Agriculture Organization (FAO) and in the World Trade Organization (WTO) throughout the 200os, the Brazilian government became a prominent actor in the dialogue between governments and multilateral agencies in terms of combating hunger and the promotion of food security in Africa. Thus, the country was responsible for articulating the internationalization of important national programs to encourage family farming and small producers, such as the More Food Program (Programa Mais Alimentos), Food Acquisition Program (Programa de Aquisição de Alimentos) and the National School Feeding Program (Programa Nacional de Alimentação Escolar), in addition to promoting the internationalization of the work of important research institutions, such as the Oswaldo Cruz Foundation and the Brazilian Agricultural Research Corporation (Empresa Brasileira de Pesquisa Agropecuária, EMBRAPA) (Cabral \& Shankland 2013). However, the increase in Brazil's economic and political presence in the African continent allowed for the expansion of national and transnational companies focused on agribusiness, which from another perspective of intervention in agriculture, had a marked influence on Brazilian foreign policy (Garcia \& Kato 2016).

Despite the numerous criticisms made about PRODECER regarding the creation of a mass of landless rural workers and small farmers unable to compete with the large producers, together with to the environmental impacts resulting from the use of chemical pesticides, an increasing number of trade agreements that facilitated investments in commodities turned this program into a "success" that should be exported (Funada-Classen 2013). Thus, the first movements of the promoters of ProSAVANA were to highlight similarities between the Brazilian Cerrado region and the Nacala Corridor, described by them as a place of "vast unused lands," characterized by "food scarcity and poverty," located in a climatic region along the same latitude as the Cerrado.

\footnotetext{
6 As Ferguson (2006) points out, many studies on "globalization" have treated the African continent as an "inconvenient case" that does not fit the narrative line of development. Thus, "the narrative repeatedly describes the world in terms of a traditional 'before' and a globalized 'after' that leaves no place for most contemporary African social realities except in the putative past" (p.27). Moore (1999) also highlights the historical-cultural dimension as one that also escapes development interventions, since many contemporary analyzes on the theme eclipse the micropolitics through which "global development discourses are refracted, reworked, and sometimes subverted in particular localities" (p.655), by assuming that these initiatives rigidly determine local political dynamics. For Moore, particular interventions are linked to a deeper history of the ways in which governments have tried to regulate and discipline landscapes and ways of life.
} 
"A Mato Grosso in the middle of Africa, with free land, with less environmental impediment and much cheaper shipping than to China," as a Brazilian businessman stated.

Since the signing of the Memorandum of Understanding between the three countries that were part of the "Tropical Savanah" agreement of cooperation for agricultural development, in mid-September 2009, an image has been strongly linked to the imaginary of this enterprise: the $13^{\text {th }}$ and $17^{\text {th }}$ parallel south, as a link between South America and Southern Africa. The area covered in these latitudinal bands places the regions of the Brazilian Cerrado and the Savannah of northern Mozambique in relation to each other, and this cartographic perspective, a series of possible similarities could be produced and highlighted to support the South-South character of the initiative that had been outlined for the program, even though it was a triangulated cooperation with a donor from the north.

As a publication by the Japan International Cooperation Agency (JICA) points out, the idea for the elaboration of what would become ProSAVANA came up a few months earlier, during the meeting of the G8 summit in the Italian city of Aquila. At this meeting, the then President of Brazil and Prime Minister of Japan established an agreement to develop agriculture in Africa. No African country, however, was present at this meeting and only months later was Mozambique officially identified as the "beneficiary country" for this initiative (Ferrando 2015). According to its promoters, the African country was chosen as the appropriate place to receive the agricultural model of the Cerrado, since the so-called Tropical Savannahs are found in both regions.

As the aforementioned JICA document describes, ProSAVANA was an assistance program for development that aimed to achieve synergistic effects through promoting agricultural investment by the private sector, and by increasing the income of small producers (Hosono 2012). The first documents of the program also indicated that the model followed by its developers aimed at integrating private investments on a large scale with the production of local farmers through contracts with agricultural companies, through which they would receive a technical package - seeds, fertilizers, pesticides, machinery and extension services - in exchange for their production (Nogueira \& Ollinaho 2013). It was, therefore, the implantation of an intensive and marketoriented agricultural production system, which could combine investment and technical assistance. Following a proposal for rural modernization similar to that which occurred in the Cerrado, the Nacala Corridor could then become the "granary" of Southern Africa.

It is believed that creating large-scale, modernized farms using industrial techniques on this underproducing land will reap high yields in both commodity crops and financial profits. This is where Brazilian agricultural development projects have focused their efforts: on providing the scientific and technological basis for improving farm productivity in sub Saharan Africa. In the words of an EMBRAPA soil scientist, the aim is to create "intelligent farms in any part of the world" (Wolford \& Nehring 2015: p.210).

However, for the knowledge that enabled the increase in productivity in the Cerrado to serve as a basis for the new enterprise, it was necessary to emphasize the similarities between the two regions, in a way that made the "transfer of technologies" and the choice of the north of Mozambique feasible, which, as the laboratory director described, was not the first site selected for the implementation of ProSAVANA. As underlined by Wolford and Nehring (2015), the idea that Brazilian cooperation would focus more on partnership than on development assistance, expressed several times in the media, in official documents and in comments by Brazilian and Mozambican government representatives, is connected to the notion of similarity. This discourse on shared affinities (Cabral and Shankland 2013) is the first entanglement that I would like to highlight. Encompassed by the image of "parallels," the similarities between the two countries is often invoked based on three main elements, with specific temporalities: a shared ecology, history and culture (Wolford \& Nehring 2015; Shankland \& Gonçalves 2016; Cesarino 2017a; Camana \& Almeida 2018). 
As Funada-Classen (2013) indicates, "Tropical Savannah" is a climatic category in the classification system established in the nineteenth century by geographer Wladmir Koppen, who describes a region in which periods of rain and drought alternate. According to the author, this was the reference for the first JICA documents when drawing the comparison between the Cerrado and the Savannah region of northern Mozambique, referring mainly to the overarching latitude to take the "success of the Cerrado" to the Nacala Corridor. The same Cartesian logic "that aligns spaces as equivalent through latitudinal similarities while abstracting ecologies and landscapes through categories such as the tropics, savannahs or corridors" (Wolford \& Nehring 2015: p. 212), was also used by Brazilians.

Thus, since the two regions are located in the tropical zone of the globe, similarities in relation to the type of soil, climate, rainfall regime, vegetation, were presented as comparative advantages of Brazilian cooperation vis-à-vis other emerging donors, such as China, or even in relation to traditional donors from the north and former partners of the socialist bloc. A selective analogy, similar to the orientalism described by Said (1979), that from a metonymic mechanism took parts for the homogenized whole (Cesarino, 2014).

An example of this mechanism can be found in the Paralelos project' developed by EMBRAPA, concurrently with the first ProSAVANA agreements. This project sought to map the territory of the Nacala Corridor to generate an ecological and geographic database through satellite information systems. Reiterating certain trends expressed in documents produced in that period by international bodies, like the World Bank, the project was an important tool for building this parallelism, emphasizing not only a latitudinal equivalence, but a prehistoric territorial proximity between the two continents that assist in dealing with ecological characteristics, such as a shared tropical climate and geological landscape. The "transfer of technologies," therefore, reinforced a "natural partnership" between the regions to build a "bridge over the Atlantic" (World Bank \& IPEA 2011) and reconnect regions that prehistorically had been one. Through the production of this set of data and artifacts, the idea of a shared nature between the two countries operated as one of the agents for the promotion of ProSAVANA (Camana \& Almeida 2018).

The second connection made between the two countries is that of the shared legacy of Portuguese colonization, which, for example, resulted in a common language. The use of Portuguese by Brazilian cooperators appears, therefore, as an advantage in relation to other donors in the north and also justifies Brazilian participation as a kind of mediator for Japanese cooperation. Wolford and Nehring (2015) and Cesarino (2017a) also indicate the importance of discourses like that of Gilberto Freyre's lusotropicalism to legitimize the idea that "future Brazils" could be gestated in African countries of Portuguese colonization.

Despite being widely used by Brazilian cooperation, the assertion of similarities as an advantageous mechanism for the implementation of development projects is a factor also highlighted by other "emerging donors." In general, a past of common colonial subjugation has served to legitimize the precept of horizontality in South-South cooperation, focusing on the technical character of the interventions, which are presented under an aura of scientific neutrality, before the political precepts of these undertakings (Shankland \& Gonçalves 2016).

Highly connected to this second similarity, the third is also based on a colonial legacy: slavery. Brazilian cooperation, as expressed in many speeches by ex-President Lula and his ministers, was a way of reversing a "historic debt" arising from the traffic of Africans to Brazil. Positively presented, the "common roots in indigenous Africa" (Wolford \& Nehring 2015: p.213), in addition to the use of Portuguese as an official language, evidenced a bond not only based on the African cultural matrix developed on Brazilian soil, but on blood. Which, according to the Brazilian government, implied a moral duty of cooperation between the two countries.

Concerning the Paralelos project, see Batistella \& Bolfe (2010). 
These elements were synthesized by ex-president Lula during his speech ${ }^{8}$ at the dinner offered by the then president of Mozambique, Joaquim Chissano, in 2003:

Brazil has a historic debt and, consequently, needs to contribute decisively to the payment of that debt. (...) We know that Brazilian society was constructed with the work, the effort, the sweat and the blood of a large portion of Africans, who were free citizens in Africa and became slaves, to provide services in my country and in other countries. The most correct way to repay the sacrifice that Africans have suffered is to establish the most perfect policy of harmony with Africa. (...) We came here to tell President Chissano that we, Brazilians, and the Brazilian government want to dedicate part of our time, part of our technological lknowledge; we want to dedicate our industrial knowledge, our agricultural knowledge, so we can contribute to the development of this part of planet Earth. (Da Silva 2003: p.2; emphasis added)

As shown in the figure presented below, not only were the aforementioned ecological, linguistic and cultural similarities emphasized, but other elements of analogy could be produced from them that would locate the three countries in a relationship within the proposal for international cooperation brought by ProSAVANA. The "challenges," the "learning opportunities" and the "vision of the future" would also be shared. And from this projection of similarities between the territories in question, a specific temporality was also composed. To ensure the emergence of the time for South-South cooperation, different temporalities became entangled: a prehistoric geographical complementarity between the continents, the history of colonization and, finally, a prospecting for the future in which the Brazilian experience - its time on the move, as Mbembe calls it - could be reproduced in Mozambique.

Figure 1: ProSAVANA presentation [translated]

\section{PIIAM PROSAVANA PROJECT}

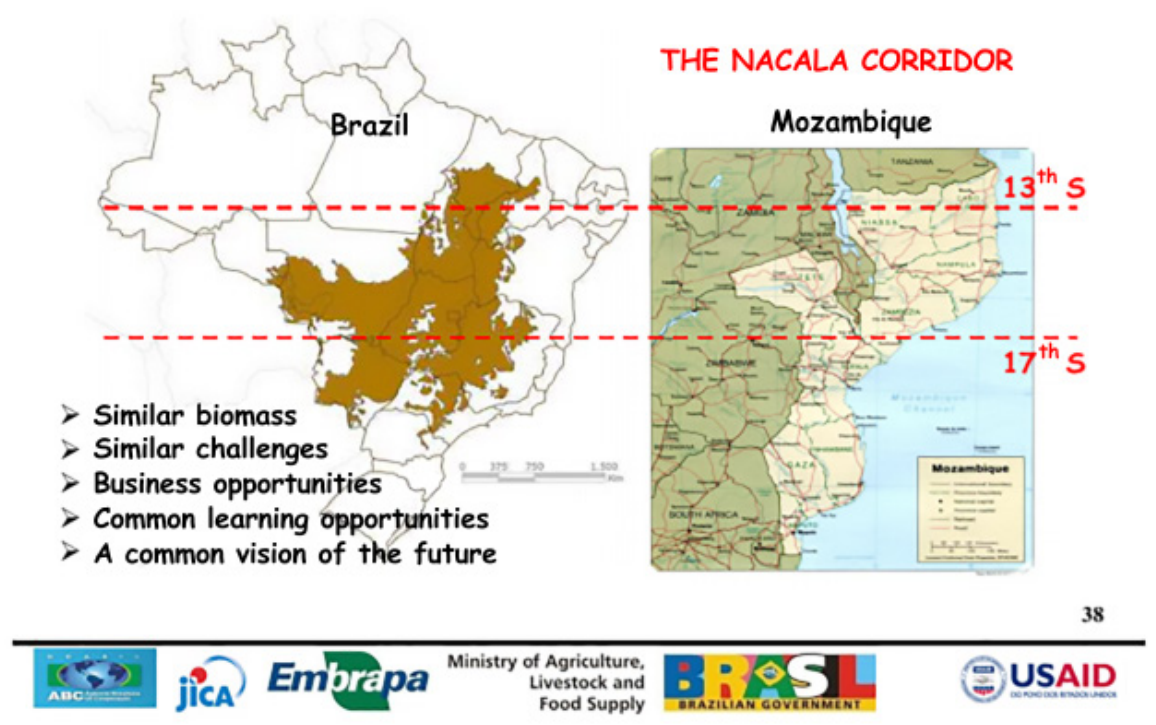

Source: Mozambique Institute of Agricultural Research (IIAM).

\footnotetext{
8 Wolford and Nehring (2015) highlight the way in which this construction of cultural similarity between Brazil and African countries also appears in Lula's speech in Ghana in 2008, when the president visited the Embrapa office opened in that country. In his speech, the president affirms that the Brazilian people were similar to the African peoples in their color, their joy, their dances and in much of their culture, reinforcing the bonds more than the barriers created by slavery.
} 
The choice of this African country as the third element of the proposal for international cooperation is not, however, due only to the resemblances between the two countries, which are mostly only sustained at the cartographic scale, or in the rhetoric of the foreign policy of the cooperators. The proposal appears in the midst of a group of other political movements that intersect with the program's initiative, creating a specific composition of relations with singular temporalities, which can be framed only within the technical discourse of international cooperation with some difficulty. Thus, despite this effort to create similarities, the first actual technical visits to the ProSAVANA implementation site showed that the resemblances between the regions were not so considerable, since other elements would become entangled in this discourse on "parallels."

As narrated by a local government official from Nampula, who followed the program's initial activities, it was very difficult, for example, to reach the peasant communities who speak Macua, a language of the local ethnicity, to hold discussions with technicians who spoke "Brazilian" (remembering how the lived experience had already modified the language spoken in both countries), Japanese technicians speaking English, or Mozambicans "from the south," who did not speak the local language. He also reports that language was not the only problem that was asserted, deconstructing the idea that it would be a facilitator for cooperation, but the discourse of cultural proximity was also not maintained; in the moments reserved for the foreign technicians' lunch, they went to their air-conditioned cars to eat bread and drink bottled mineral water, while the peasants "remained to eat dry cassava." He argued, sarcastically, that the co-workers should have brought water in canteens, since the communities already knew about them "from the time of the settlers."

In his opinion, these "communication problems" resulted in the series of resistances faced by the technicians when taking ProSAVANA from the scale of plans to "the terrain." In the next section, therefore, I seek to discuss some implications of these resistances for the temporality of program implementation.

\section{Adjustments in the speed of technology transfer}

An important element of differentiation that came to counter the discourse of the parallels between the Savanah and the Cerrado is the high population density of the Nacala Corridor region. In addition to being a region with considerable water resources, northern Mozambique has very productive land, which is the reason it is one of the most populated areas in the country, principally in the vicinity of the railroad that crosses the corridor, the highways and the few roads that integrate the rural households with larger urban agglomerations. Much like in the entire country, the Nacala Corridor is inhabited by different ethnic groups. The northern region in general, is home to the largest ethnic group in Mozambique, the Macua. Other groups also live in this territory, such as Macondes, Lomues, Ajauas and Nyanjas, who speak their own languages. As the above report indicates, Portuguese is not the first language spoken by this population, especially in rural areas where the vast majority live. 
Figures 2 and 3: Houses next to the road in a peasant community
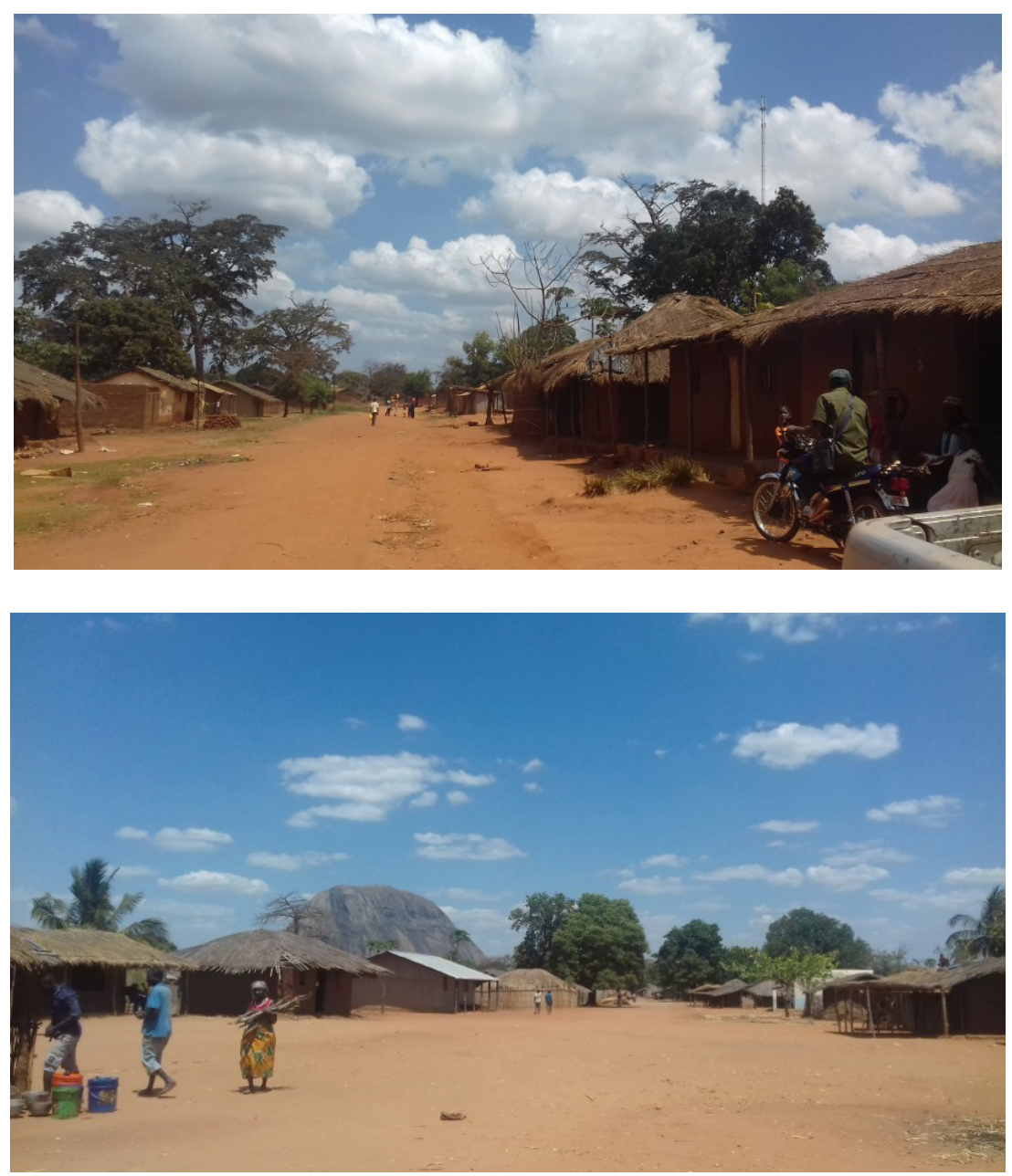

Source: The author, in the field.

Doing semi-nomadic agriculture, these groups are mostly organized in peasant, matrilineal communities, living on subsistence agricultural cultivation or with few surpluses, drawing on family labor and community members to maintain agriculture in their areas. Mainly women work in the machambas, ${ }^{9}$ while the men are responsible for the exchange and commercialization of the products. However, these rural households are generally poorly integrated into the market, as they are distant from the main marketing centers and find few possibilities for distribution. The intercropping of food crops, such as manioc, corn, beans and vegetables, in addition to the reservation of rotating fallow areas to maintain the fertility of the land, have been the main cultivation techniques employed by peasants in community areas that generally occupy approximately one hectare, ${ }^{10}$ worked with short-handled hoes and machetes.

\footnotetext{
Agricultural production areas in Mozambique are called machambas.

10 For a more detailed description of the farming done by small Mozambican producers in relation to land occupation, and the production methods and technologies used, see Smart and Hanlon (2014) and Uaiene (2012).
} 
Figure 4: Photo of the collective fields of a community in Ribaué

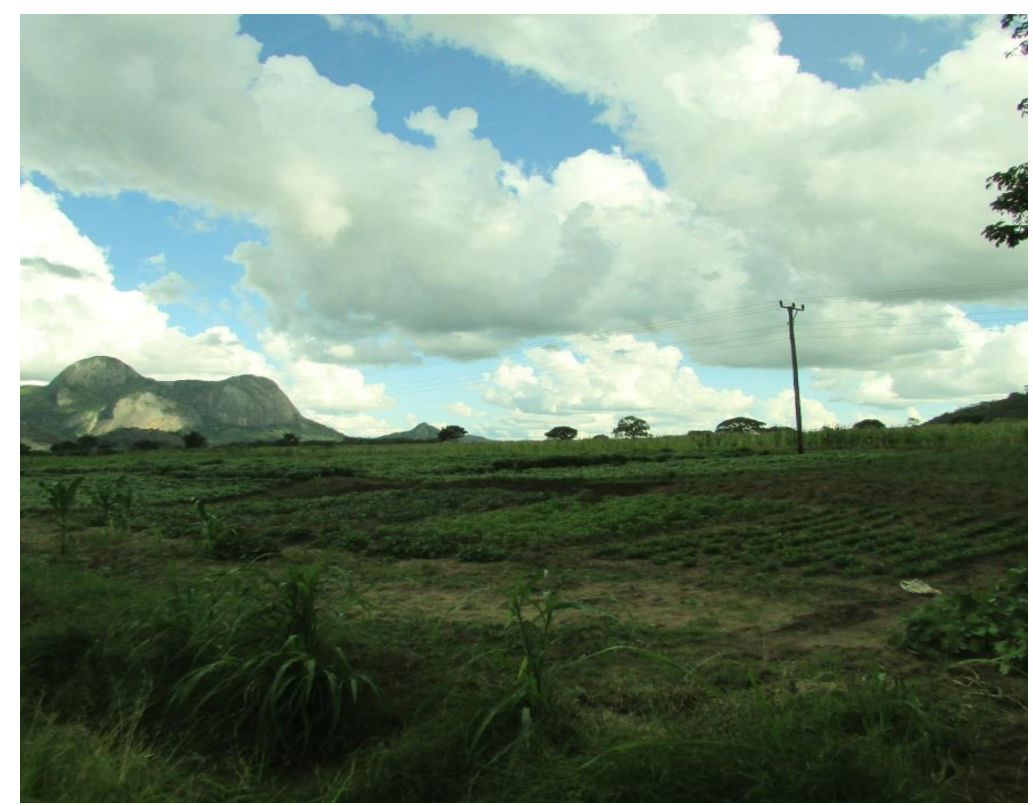

Source: The author, in the field.

In addition to these singularities of Mozambican rural environment, it is important to note that land ownership in Mozambique is state owned and can be used through an annual tax of approximately six dollars per hectare for fifty years, and renewable for the same period. However, the aforementioned peasant communities have the right to traditional use of their community lands, and do not require a Right of Land to Use and Benefit (Direito de Uso e Aproveitamento da Terra, DUAT) document to occupy them. ${ }^{11}$ Due to this rotation system of cultivated lands, it is difficult to find extensive continuous agricultural areas. It was not, therefore, "free," "empty" or "available" land for large investors, as stated in some of the first discourses concerning ProSAVANA."

Faced with these specificities, the developers of ProSAVANA had to modify the program's approach in its preparatory phase. Beyond the similarities of climate and latitude in the area encompassed by the "parallels," they began to highlight agronomic similarities not taken advantage of by the peasants of the region, given the lack of investments and the appropriate techniques to increase productivity. In this case, the techniques developed by EMBRAPA and the investment of large companies producing commodities for export.

\footnotetext{
11 According to the Land Law, "As a universal means of creating wealth and social well-being, the use and enjoyment of land shall be the right of all Mozambican people. (...) Ownership of land: exclusive right of the state, established by the constitution of the Republic of Mozambique incorporating all rights of ownership, as well as the power and the ability to determine the conditions of its use and benefit by individual or corporate persons. (...) The land is the property of the State and cannot be sold or otherwise alienated, mortgaged or encumbered. (...) The application for a title for the right of land use and benefit shall include a statement by the local administrative authorities, preceded by consultation with the respective communities, for the purpose of confirming that the area is free and has no occupants." (MOÇAMBIQUE 2004: 1-5).

12 I would emphasize that the production of territories as empty areas is nothing new, rather it is a common way of operating the development apparatus. In general, the space which the state (articulated with international cooperation) intends to develop is produced as a demographic, sociocultural and even environmental vacuum, both in terms of discourse and interventions that result in population displacement or the degradation of a given biome. Considering the Brazilian case, it is possible to observe how this invisibility mechanism was present in the policies of occupation, modernization and expansion of the agricultural frontier to regions of the Amazon and the Cerrado (Heredia et al. 2010; Martins 1997; Velho 1981) during the military governments and, more recently, in the MATOPIBA (Santos 2018). Projects for the revitalization of certain urban spaces, which operate in a similar manner, are also worth highlighting (Guimarães 2014). On the production of the Mozambican Savanah as an empty place, uninhabited and waiting for development, see Camana and Almeida (2019).
} 
The tropical savannah region that spreads to the northern part of the country is thought to have a high potential of agricultural production, for the land being especially suitable for farming, due to its steady amount of rainfall and vast land. This region, however, is mostly uncultivated. Furthermore, small-scale farmers are limited by their adherence to traditional agricultural practices, which are mostly extensive type of cultivation, and the productivity of both subsistence crops and cash crops are not high. Even the agricultural techniques of intermediate and large-scale farmers are limited, and not very productive. Hence, the expansion of cultivated land and increases in agricultural productivity are to be expected with the introduction of appropriate agricultural technology and investment. (JICA, February 2011 apud Funada-Classen, 2013 p. 11; emphasis added)

Since the first apparent movements toward the implementation of ProSAVANA, the União Nacional de Camponeses (UNAC) ${ }^{13}$ has condemned the concession of land to Brazilian agriculturists dedicated to agribusiness, through an initial pronouncement concerning the program released in 2012. In this, the protesters already highlighted the elements that would guide their criticisms, which deepened in the years that followed: the focus on monoculture cultivation, the risk of loss of land by peasants, and an exogenous model of agricultural production that would rupture with elements of the sociocultural organization of the populations of that region. The declaration was drawn up from a meeting held in the same year between peasant communities to discuss the progress of the program and access to information on it, since the elaboration of a Master Plan already appeared to have begun, without the corridor populations actually having been consulted, as stipulated by the Mozambican Land Law.

The first public information about the program came from an article published on August 14, 2011, in the Brazilian newspaper Folha de São Paulo, under the title "Moçambique oferece terra à soja brasileira" [Mozambique offers land to Brazilian soy]. It states that an area of approximately six million hectares would be available under a concession regime for Brazilian businesses linked to agribusiness to grow soy, cotton and corn. For many peasants, however, the meeting organized by UNAC was the first time they received information on ProSAVANA. From that point on, some Mozambican organizations began to work on verifying the existing information with their government, however, this would have brought little clarification on the terms and conditions of this "offer to Brazilian soy."

Criticisms about the lack of transparency and a participatory process in the elaboration of the program intensified after the unofficial disclosure via internet of a first version of its Master Plan, in early 2013. Denominated Report no. 2, the document established the area covered by program activities, which would be approximately 14 million hectares, comprising 19 districts located in the provinces of Nampula, Zambézia and Niassa. In addition to the fact that this large area is often presented as available to investors in Mozambican government discourses, disregarding the population of approximately 4.5 million inhabitants in the region, recommendations for the formation of productive clusters in the document drew the attention of organizations and social movements:

Clusters are strategic approaches to accelerate development within a specified territory. The central line of development of these strategies is to design one or more value chains, with synergic potential and in appropriate context regarding the territory, in order to channel efforts for its realization within a period lower than that which could be achieved without integrated and specific actions. All producers, companies and institutions that are correlated with the central value chain, such as input suppliers, machinery suppliers, specialized infrastructure or competing entities, represent the constitutional elements of a Cluster.

\footnotetext{
13 UNAC [National Union of Peasants] is a Mozambican platform for peasant representation that was established as a social movement in 1993, following the end of the civil war and due to the neoliberal economic restructuring that the country is undergoing. It has been created to be a national organization "of peasants" rather than "for peasants," as one of its founders says, in contrast to the previous General Union of Cooperatives organized within the scope of socialist planning. UNAC branches into Provincial Unions and, more recently, has fostered the formation of District Unions and advocacy agents trained to mediate relations between the organization (and local government) with peasant communities.
} 
Clusters also involve marketing channels and consumers as well as producers of complementary products and companies of related sectors. (...) The production clusters present themselves as the basis for the political, social and especially economic development of Nacala Corridor. Each cluster will encompass a variety of agricultural, industrial and service providers companies, where will be involved corporate domestic and foreign producers up to the Mozambican smallholders working together in synergy between components (PROSAVANA-PD 2013: 2-14; emphasis added).

As the document indicates, such clusters would be constituted based on zonings in the Nacala Corridor region, classifying it into different classes of agricultural management through a wide mapping of the territory in order to determine the different types of soil, climatic variations and agroclimatic conditions, productive scales, potential human resources and degree of access to arable land, through integrated actions elaborated based on the agricultural potential, land use mode and environmental restriction of each region. Thus, one of the main objectives to be achieved by this proposal for the productive reorganization of the area covered by the program was to accelerate the results of agricultural development.

Initiating the preparatory activities for the formation of these clusters, the document listed 16 priority projects - the Quick Impact Projects (QIPs) - to increase the productivity of the value chain to which they applied, generating visible impacts and results in the short term. ${ }^{14}$ In order to guarantee the speed of development, meeting the political demands of the Mozambican state and quickly generating the "success of the Cerrado" in the Nacala Corridor, the results of the QIPs would act as showcases of the region's agricultural potential, in order to attract donors to finance other projects proposed in the Master Plan, in addition to national and international companies that could promote agribusiness plans in the region.

Most of the fast impact projects, however, did not precisely define their beneficiaries, location or magnitude, making it practically impossible to measure the size and quality of their results. Many still required environmental impact studies and indicated the need for expropriation of local peasant populations. Such issues deepened the national and international demonstrations against ProSAVANA. A number of organizations and social movements publicly opposed the program, claiming that with the arrival of massive foreign investments, peasants in the region would eventually be removed from their land as a result of the indebtedness that a contract work regime can produce, or by resettlements put forward by the Mozambican government, both proposals present in Report no. 2. Criticisms were also directed at the possible loss of autonomy of peasant families not only in relation to the land, but also what is produced in the areas of community use, resulting in implications for their diet and a reduction of the peasants' quality of life, in a context of the progressive loss of their consuetudinary rights.

As Shankland and Gonçalves (2016) highlight, the allegations of similarities based on the landscape that brought the Brazilian Cerrado and the Mozambican Savannah together had a particular productive force that allowed both to promote South-South cooperation and to question it. Also supported in the results of the PRODECER a transnational network contesting the program was then built based on this search for more information. Since 2014, civil society organizations and social movements in the three countries involved in trilateral cooperation have maintained an anti-program campaign - the Não ao ProSavana [No to ProSAVANA] Campaign - which, together with advocacy work with the governments of their own countries, in the dissemination of documents in the peasant communities, the articulation meetings between organizations, social movements and communities, the publication of papers positioned against the program model and even through boycott activities, have managed to delay or even paralyze some ProSAVANA activities.

14 In some of the projects, it was expected that after three years it would be possible to glimpse "improved productivity and increased income of beneficiaries, introduction and promotion of improved agriculture technologies such as quality seed, fertilizers, agriculture machinery, and post-harvest technologies, and the construction or rehabilitation of rural infrastructure related to agriculture development" (PROSAVANA-PD 2013: 4-1). 
One of the most striking effects of this process of resistance has been the reformulation of the Master Plan, which should have been completed in 2013, but is still being prepared. In the most recent version of the document, called Draft Zero, it is notable that together with the focus on small producers as the target group of the program, a series of food crops has also become more relevant. Although "an analysis of the evolution of the areas of the different crops referred to in the MP-Version Zero, between 2011 and 2030, clearly indicates that soy will evolve much more rapidly than the remainder" (Mosca \& Bruna 2015: 16), such that it will be the crop that most receives the improvements in "technology transfer."

A second important element of this process of resistance was the pressure to hold public consultations with the peasants who would be affected by ProSAVANA projects. Based on the criticisms and demands from the communities of the Nacala Corridor, peasant associations and the articulation of civil society organizations from the three countries, expressed in a series of documents, the Mozambican Ministry of Agriculture convened the so-called "Public Hearings on Draft Zero of the ProSAVANA Master Plan," in 2015. However, these meetings brought even more conflict to the situation. The protests began because the hearings were organized to present yet another ready-made version of the Master Plan, without having previously established the "democratic, transparent and inclusive" dialogues requested in an Open Letter ${ }^{15}$ two years previously.

After the hearings, the organizations of the Não ao ProSavana Campaign wrote a series of denouncements. Signed by more than sixty national and international organizations, the "Call of the Peoples for Immediate Invalidation of the Public Hearings of the ProSAVANA Master Plan," emphasized that the meetings had no legal basis, as they ignored the legal instruments that define the guidelines for public consultations in the country. According to the protesters, the organizers deliberately used delays, changes in locations, the selection of participants, and making it impossible to understand the contents of the document (because it was not made available in a timely manner for analysis) to prevent interventions. ${ }^{16}$

In this great dispute over the legitimacy of community consultations, it is possible to apprehend a second entanglement of different emerging temporalities as an effect of the power relations that traverse the implementation of the program of cooperation. While the work of the technicians seeks to guarantee the speed of the processes to achieve development, it crosses not only the obstacles brought by the slow time of bureaucracy expressed in the production of different versions of documents, but also the temporality evidenced by the communities that refused to accept the disclosure of a previously completed technical document as an appropriate consultation. For critics of the program, the construction of another development proposal was necessary, a movement of a slower nature, which would fundamentally imply the participation of the peasants not only in community consultations, but in the formulation of ProSAVANA in general. This is demonstrated by the statements of the president of a peasant-based organization and the coordinator of a Mozambican civil society NGO, which I reproduce below:

\footnotetext{
15 In May 2013, the demonstrators drew up an "Open Letter to Deter and Urgently Reflect on the ProSavana Program," addressed to the presidents of Mozambique, Brazil and the Prime Minister of Japan. It called for the immediate suspension and review of ProSAVANA and proposed another technical model of agricultural development, understood as more sustainable for the region: an agriculture based on production systems and not on products, which respected the peasants' family production logic and their way of occupying space in its social and anthropological dimension.

16 The first version of the master plan was just under 300 pages long. Although successive versions of the document are getting smaller, it is important to remember that these are communities with low levels of education and whose first language is not Portuguese. Therefore, it would be very difficult to analyze a technical document within the limited time proposed by the program managers. Many protesters also denounce the creation of an intimidating environment for peasants through the presence of uniformed armed security guards at the meetings, together with threats and the harassment of peasants who expressed objections to the program.
} 
These are saying that the Version Zero Master Plan has changed (...). It changed because in the Master Plan, that of 2013, there was only corn, soy and sugarcane in there. (...) Now there's peanuts, beans, cotton, cashew nuts. Perhaps they consider it a change, but what we're saying is, not yet! Nothing's changed. First thing is that they should have left everything out. Leaving it all out, the first thing was to do the field work. Go to the base, sit with the peasants. To hear the peasants. Listen to the peasants, what concerns they have, what kind of support they need, and all that. And so, after spending time in the communities, the technical team could sit down and produce the Master Plan. And this Master Plan, after its produced, has to go back to the peasants. And it would remain there for two, three, four months. For the peasants to try to read it slowly, see if it's exactly what the peasants had reported. And then you could hold community consultations, but that's not what's happening. There's a lot of manipulation and there's no transparency. A lot is happening in ProSAVANA's space. They are advancing, but the base there, the peasants there, were not informed. (Peasant leader)

Unfortunately, in the Mozambican government, things are like that, things have to happen from one day to the next. In my opinion, this does not ensure, it does not guarantee the quality of the work. (...) Every single time we tried to have community consultations, things were like night and day. Like, we have to do the consultations next week, or next month. We commented among our colleagues here, sorry there, we have our work plans. The peasants also have their activities, their plans. (...) These activities should be part of our work. And to be part of our work, it can't appear and be included in this month's plans, for example. It has to be fitted into the plan two, three months ahead. (...) And I think that because of the way ProSAVANA itself was brought over... I've no doubt that there was political pressure. It has to happen. A done deal. (Member of Rural Association for Mutual Support, ORAM)

This criticism was not restricted to protesters who oppose the program, but it was also emphasized a lot by ProSAVANA technicians. According to a former extension project coordinator, "there was a lack of thought and observation of the specificities of the country." When evaluating the results of the interventions already carried out, unlike the rhetoric of "technology transfer" between "parallels," his analysis indicated the absence of deeper field research on the program's target region. For the coordinator "whoever drew up the first documents did not have this dimension." As I will present below, to face these criticisms, the solution found by the proponents of ProSAVANA was to fit it into another temporality - that of the experiment.

\section{The experimental time of development technopolitics}

In conversations with technicians linked to ProSAVANA in different districts that already had ongoing experimental activities, they were concerned enough to emphasize that no peasant had lost land. Using as reference the most recent version of the Master Plan, prepared after the various criticisms received over the years, they highlighted that the focus of the next steps was to increase productivity in the cultivation of the "banner crops" of each district, listed in the Strategic Plan for the Development of the Agrarian Sector (Plano Estratégico para o Desenvolvimento do Sector Agrário, PEDSA) of the Mozambican government and the integration of small producers into the region's production chain, improving their access to the market.

Thus, just as the temporalities of bureaucracy and resistance affected the speed of the program's implementation, an experimental period emerges as an official technical discourse that responds to the challenges faced. As a representative of JICA pointed out, the problem of high population density in the Nacala Corridor or the need to carry out socioenvironmental impact studies indicated by the campaigners of the Não ao ProSavana Campaign, were not seen as major obstacles to the continuity of the program, since that the activities conducted thus far were still preliminary studies for the structuring of what ProSAVANA would become: 
One of the minor constraints that we found concerning the difference between PRODECER and ProSAVANA has to do with population density. In Mozambique, the Nacala Corridor is the most densely populated zone. Just to give you an idea, if we combine the provinces of Nampula and Zambézia, it's just over 50\% of the population of Mozambique. ${ }^{17}$ Therefore, there can't be large tracts of land available in that area. (...) It must be said that the program is not being implemented as ProSAVANA, as such. Both the research project and the extension project have yet to find out how we're going to implement it. And the master plan will decide exactly which projects to implement. It's more about research and the search for models. (...) And so far, we haven't seen any need to commit to the study of environmental conditions, because no project has been designed. So, probably a posteriori, if a project appears that could have an environmental or social impact, we'll do the necessary studies. Now it's all about research. Finding out exactly what's happening at the field level. (JICA representative)

ProSAVANA is structured around three preparatory projects - the Investigation Project, the Extension and Models Project and the Master Plan - that should be developed over a twenty-year horizon. Characterized as the "technology transfer" component itself, ProSAVANA-PI (Projeto de Investigação; Investigation Project) began in 2011 and ended in 2017. This step aimed to strengthen the operational capacity of the IIAM and develop new agricultural technologies in demonstration units.

EMBRAPA technicians have acquired a central role in this component, since they are the holders of knowledge in tropical agriculture that is proposed to transfer and adapt from the Cerrado to the Mozambican Savanah. Within the scope of ProSAVANA-PI, therefore, some food crops and soybeans for the production of feed were tested and improved seeds have already "released," that is, they have the certification that allows them to be commercialized, from the germplasm of Brazilian seeds or from local varieties. Again, in this component, Japanese cooperation handled the construction and supply of equipment for the Nampula Laboratory of Analysis of Soil and Plants and for certain tests on varieties of seeds (corn, soybeans, beans, peanuts, rice, sorghum, vegetables and cotton). ${ }^{18}$

In addition to the sustainability problems of the laboratory that the director highlighted, and from what I was able to accompany in seminar that released the ProSAVANA-PI results, many of the technicians questioned the ability of small farmers to use the laboratory apparatus, since integration with the extension activities has been weak. Currently, its main users are researchers and businesses, in their soil analysis and seed acquisition. The sustainability of the transferred technology, therefore, appears to be another entanglement that I would like to highlight. It emerges in yet another specific composition of different temporalities that become entangled with the "time of the experiment", displacing its execution under laboratory conditions, which occur as if they were isolated from external agents that could influence their results.

According to Latour and Woolgar (1997) after the purification process that isolates the political characteristics from their own condition of production, evading the sociological or historical explanation of their construction, the scientific fact ${ }^{19}$ could only transit unchanged if there was a standardization of the sociotechnical networks outside the laboratory. "But what about laboratories that are not well equipped, where technicians are not well trained or assiduous and energy or basic materials may be lacking at any time, that is, where the fact or technoscientific object is not 'effective'?" (Cesarino 2017b: 73).

\footnotetext{
17 The situation in Niassa Province is a little different. At the height of the Cuamba district, where the main section of the railway ends, together with the Nacala Corridor itself, the province is still quite populated. However, new districts were added to the initial project, such as the Sanga region, where there is a greater area of continuous arable land. For this reason, the area that would be occupied by the project varies between 7 and 14 million hectares (taking into account that this is the area of impact/influence of the projects and not of occupation). On the other hand, this region is home to numerous forest reserve areas, which may be at risk from program activities.

18 Brazilian cooperation, however, was unable to meet all the commitments agreed upon, due to a lack of resources. The laboratory that was to be constructed in the city of Lichinga, for example, was never built and visits by Brazilian technicians are practically nonexistent.

19 For Latour and Woolgar (1997), a scientific fact is recognized as such when it loses all its temporal attributes - its historical reference - and is integrated with a whole set of other knowledge already established as purified facts.
} 
In the case analyzed here, an important moment in which the sustainability of the technology called into question the efficacy of the experimental temporality in which the program has been developed was the use of improved seeds. Local seeds have a long cycle, that is, slower growth from sowing to harvest. In contrast, the improved seeds have a shorter cycle, which is one of the fundamental factors that not only increases the quantity of what is produced, but accelerates the speed of production. Thus, the seeds improved by Brazilian technology are presented as the most appropriate, since they produce faster and in a more standardized manner than the native seed in the same harvest. However, their productivity is only maintained when combined with the use of certain inputs, such as fertilizers and pesticides. This implies costs that currently cannot be maintained by small farmers, which is a criticism that has already been raised by ProSAVANA technicians concerning the sustainability of the projects tested, many of which were abandoned by the peasants.

Thus, the main consequence of applying the technical package of the improved seeds is the generation of this dependence in relation to the use of inputs, which had to be constantly acquired by farmers to maintain the productivity of their areas. On the other hand, although they present problems related to a lower fertility and are vulnerable to the recent changes in the region's rainfall patterns, native seeds are better adapted to local agroecological conditions, they are more resistant to periods of drought and, when fertilizer applications are not possible, in remaining productive over a larger number of crop cycles.

It's not that we don't want better seeds. We do, but the seed we receive is a seed that creates problems, a dependency for the peasants. Because our system is: the peasant sowed this cycle, corn, it's the same seed that he'll use in another cycle. (...) For two, three, four generations of seeds, it produces. But unfortunately, the improved seed does just one cycle. (...) This is where we're [questioning] what kind of technologies are these? Will they help farmers raise the level of production, or will they create more dependency? (...) We want development, but an endogenous development, in which communities participate in the process. (...) We have to improve our local seed. There are problems, we recognize that. But we have to improve this one, our local seed, because it's that seed that adapts to the environment, adapts to climatic conditions. There's an excessive dependence for the peasants. Every cycle, the peasant has to buy seed. In other words, we're feeding the multinationals. (UNAC Representative 1)

And as we can see, the master plan, ProSAVANA itself, saw the peasants as a component to support agribusiness. I mean, the peasant had to buy that commercial seed, which he has to buy season after season. Always dependent on that kit of fertilizers or pesticides to develop the crop in the drought. Not in the sense of ensuring that the models that the peasants already used were maintained, or at least were combined with the model that they intended to install. It's like a landed estate, companies are installed there in vast areas and the peasants are only there to supply labor, buy seeds, buy pesticides, but not to preserve their production models. (UNAC Representative 2)

From the statements highlighted above, it is possible to perceive how the time of the different seeds changes the mode of production that has been followed by the peasants in the region by proposing an intensive use of the areas, since the use of fertilizers means it is not necessary to rotate the fields of cultivation. However, by making to this mode of field production ${ }^{20}$ dependent on the use of inputs, it relates the increase in productivity to the production of surpluses to be exchanged in the market. There is a shift from a cyclical temporality in the rotation of soils and crops, to the progressive and sequential time of development.

\footnotetext{
20 The peasant's way of production was described thus by a peasant leader: "Our land here is very, very fertile. And we're also used to having a machamba here of a hectare, or two, or three hectares, for example, of corn, or sorghum, or beans, but then we have to move away from here. We have to go down [to the river] to open another machamba for rice production. Later, we have to go to other places, we open another machamba for the production of other crops. (...) We are also used to producing here for two, three, four, five years, or six years. It depends on the soil. Then we let it rest. We're going to open a new machamba. To replace that machamba that we're leaving fallow. We open a new field and this one, we let it fallow. If we let it rest, it doesn't mean that this land is abandoned land. It doesn't mean that this is land that's not used. No. We let it rest so that the soil can absorb nutrients again, to guarantee production. (...) After a few years we realize that no, this soil now, production is falling. Without using chemicals, we leave it fallow. We came back to this old field. We reopen it again. We produce like this.”
} 
According to one of the technicians responsible for ProSAVANA-PEM (Projeto de Extensãa e Modelos; Extension and Models Project), there is indeed a risk in the dependency created by the use of improved seeds. He said that initially the proposal of the Japanese cooperants was to work with the certification of local seeds, which "would merely go through some selection." They would thus work with the farmers' own seeds, offering technical assistance to improve their cultivation. However, there was a lot of pressure on the part of the Mozambican government to use the seeds improved by Brazilian technology. The technician also highlighted that in Mozambique "technical power has no independence," so they had to adapt the program to the demands of "political power." From his perspective, this has been one of the reasons for the failure of many interventions in the country's agricultural sector and he therefore questioned what would happen from 2019 onward, when ProSAVANA-PEM assistance would end. "Does the government have the capacity to make seeds available to farmers?" He believed not.

Considering that the peasant communities have low integration with the market, local or export markets, in addition to having a minimally monetized economy, the sustainability of these packages would only be maintained in a kind of ideal laboratory condition created by international cooperation when supplying the inputs for the production. Thus, in order to better promote this transition from peasant to commercial agriculture, ProSAVANA-PEM aimed to establish pilot production projects in commercial and family agriculture, by offering extension services. This stage began in 2014 and ended in 2018, and was the component responsible for the so-called win-win integration between small, medium and large producers.

Figure 5: Extension models tested by ProSAVANA-PEM [translated]

\section{Models introduced by the PEM}
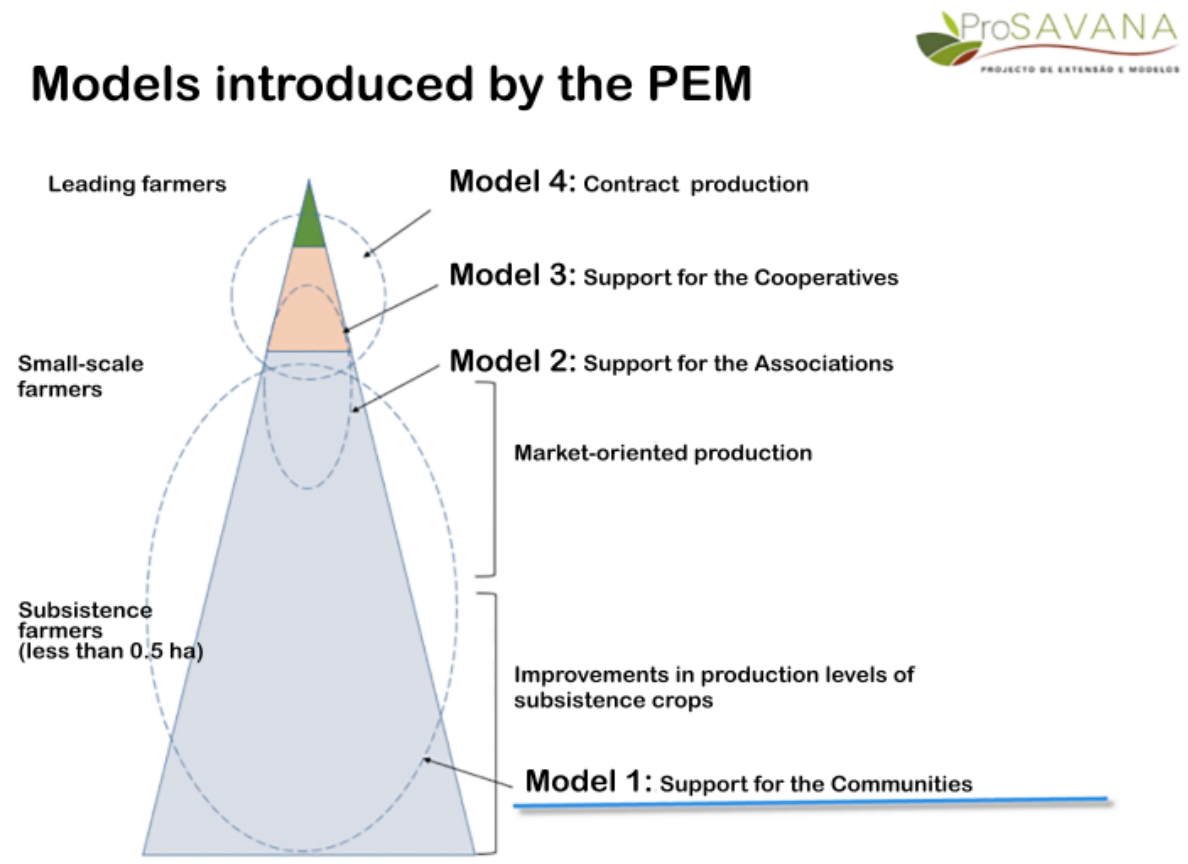

Source: https:||www.prosavana.gov.mz/portfolio-items/video-prosavana-2019-sobre-novos-modelos|

As figure above shows, four models were tested, each expanding the scale of integration between producers and the market: individual non-associated farmers; associations; cooperatives; integrated activities between national medium-sized companies and small producers through contracts. For the execution of the projects, the selected communities were offered a revolving fund maintained by a microcredit financial agency for the 
acquisition of seeds and inputs. This fund should be repaid when the association or cooperative receives its first income, and is then lent to the next association chosen.

Thus, "financial education" activities were also carried out so that producers could organize savings for the payment of the debt, in addition to reserving a portion of the crop's income to meet their basic needs and invest in the following year's production. Thus, ProSAVANA-PEM, operated on the relation of the communities with the future time of the market and the financial system. According to a coordinator of this component, his role was "provide the worm on the hook, not the fish":

The community is selected. Once selected, what happens next is explained and they begin to participate in the activity. (...) The times that I've visited these associated groups, at least, I've felt a great enthusiasm in them. Now if you ask me, will they remain sustainable? [brief silence] I still don't have a clear answer (...). If they've really adapted to it well, then they'll become sustainable and, in a few years, they can become groups of producers with a certain differentiated status. Because they have everything to move forward. They have the knowledge, they have the training, they have all the possible packages there for them to produce as individuals with vision and perspective for transformation. To not become passive. That's the reason for delivering the first five kilos [11 lbs], to multiply this seed. And whatever you've produced, then in the following cycle, you seed the area accordingly. It means baiting the hook. You catch the small fish, you get a taste, you try to catch the biggest fish possible. So, I think that in the way it's being incorporated, the communities that really adapt to it will be very successful. (ProSAVANA-PEM technician)

Finally, the third component of ProSAVANA, the Master Plan, as discussed above, will be a plan for comprehensive agricultural development and territorial planning for the Nacala Corridor, part of a strategy to implement value chains in six logistics corridors scattered across the country. At the time this work was being finalized, it was still under elaboration due to the pressure for public consultations with the communities that will be affected by the project. According to the program's implementers, the continuity of ProSAVANA depends on the completion of this document, which will be its legal basis. Until this occurs, activities continue to take place in the experimental temporality of research and the development of extension models.

Once this stage of technical cooperation is concluded, a stage of financial cooperation will begin, in which agribusiness companies will be invited to invest in the Nacala Corridor. However, the funds that existed for the first stage gradually disappeared, both because of the many criticisms of the way the program was being implemented, and because of the Brazilian economic and political crisis that led to a retraction of its participation in the cooperation. ${ }^{21}$ One of the program's coordinators also pointed out that the dispute in Japanese civil society regarding denunciations about the concealment of information was one of the factors that led to reevaluation of the program by the Japanese parliament, which was fundamental for the suspension of the second stage.

As highlighted by Bijker \& Law (1992), technologies do not have a starting momentum that allows them to pass through a neutral social environment. On the contrary, they are subject to contingencies as they are passed from hand to hand, from context to context, being shaped and remodeled. Constituting a complex set of relations between heterogeneous elements, these technologies are not only transferred to a local situation, but need to be described, decoded and transformed, producing new patterns of relationship with the scientific object or practice (Akrich 2014). Thus, a question raised by this active experimental temporality, as if scientific activities were conducted in a kind of sociocultural, political, environmental vacuum that relativizes their

\footnotetext{
21 It is important to highlight that though the program occurred in the midst of high prices for agricultural commodities, minerals and biofuels, which brought a lot of influence to the format acquired by its development proposal, from 2013 onwards, this "commodities boom" ended. Therefore, in addition to the resistance encountered in the actuation of civil society, this change in the international economic scenario has also had an impact on the formatting of ProSAVANA projects, as they become less attractive to investors.
} 
effects, is that there is no moment in the intervention of a development program in which their activities do not have profound implications on the ways of life of the subjects embroiled in their activities and on the territory where they occur. ${ }^{22}$

With regard to ProSAVANA, since its announcement in a newspaper report in Brazil, a network of contestation processes has become intertwined with the duration of its implementation. A duration that became entangled with the temporality of the technological modernization of rural areas in Brazil, of Portuguese colonialism, of bureaucracy in the production of documents, of new improved seeds, of the traditional agricultural cycles of peasants and of the geological prehistory of two continents.

\section{Final considerations: the speculative time of development}

Despite the change in approach during attempts to implement its components, which eliminated proposals to grant large areas to international investors, and to some extent served to disqualify the criticism that the program would "usurp land," ${ }_{23}$ it is still possible to reflect on "mechanisms to open space," as a member of an NGO critical of the program called it, given the specificity of the land regime in Mozambique and the relationship of peasant communities with it. One of these mechanisms is the proposal for contract farming as a way to achieve win-win integration between different scales of producers, based on the formation of value chains and a logistical corridor that could accelerate the production of development in the region.

Based on the experience of Mozambican peasants in the production of crops that are already historic in the country, such as tobacco, sisal and cotton, what is observed are intermittent jobs, with low wages and almost negligible payments for the use of community areas. By handing over their cultivation area, or going to work in the area of a businessman in exchange for a salary, the small farmer is dependent on the payment he receives in order to purchase food. As has been said, in the case of subsistence communities, which are often completely isolated from the market, this becomes a great risk. "Money runs out, land doesn't" always reiterated the leadership of the Nampula Provincial Peasants' Union, with whom I visited some communities that were facing problems with investors who entered their lands.

The Mozambican Land Law is often cited as a guarantee of land maintenance ${ }^{24}$ by peasants, mainly by members of the local government. However, a recent movement for the concession of DUATs exists that enables us to question whether a mechanism to make the peasant communities' right of customary use more flexible is in effect. Virtually all the organizations working on land issues in the region where ProSAVANA is being implemented were involved in the delimitation and certification of community areas for the concession of DUATs and in the mapping of their "potentialities," including reserving an area for the entry of future investors (in the so-called "future vision maps" carried out in participation with the communities).

\footnotetext{
22 The effects of these large projects, therefore, do not fit into purely technical categorizations of time and space, or strictly economic compensations. The area of intervention and the changes produced are the subject of a dispute that also takes place in the field of politics and is linked to complex historical and social processes (Vainer 2008). Thus, it is important to consider that the temporality of the effects goes beyond the period of intervention of the projects. As Sigaud (1986) points out, the very announcement of these undertakings initiates a series of transformations in the place where this will occur.

23 "Usurpação de terras" [lit. Seizure of land] was the form most used by my research interlocutors to refer to the debate on "land grabbing," a generalizing term that has been related to the great increase in (trans)national land transactions in the last decades, mainly around the production and export of food, minerals, wood and biofuels (Borras \& Franco 2012). Being associated with forms of land control, more than its ownership, it can also be understood as a process of large-scale acquisition of land - whether through purchase or lease - by domestic or transnational companies, governments or individuals, in which one of the effects is the transformation of land into a financial asset disputed in the international market. On this topic, see Sassen (2013), Eldeman et al. (2013), McMichael (2014).

24 In the documents that support ProSAVANA, the only guarantee presented is the "good conduct" of entrepreneurs when implementing voluntary contracts and principles of "corporate responsibility" and "good governance" (Morais 2014).
} 
However, when talking to communities and individual peasants, the fear that they had of losing their land was evident, even if it was documented. They commented that if "the state is the owner of the land," it could decide what the "use and benefit" of these areas means, or the criteria for defining the valid forms of their occupation, and hand them over to an investor. According to the organizations that are against ProSAVANA, this is one of the "mechanisms to open space" and produce these free, empty, available lands. They feared, therefore, that the individual DUATs, whose concession was provided for as part of one of the QIPs, could be used as guarantee of payment of some debt of the communities with financial agencies that have been working with the development projects.

This would be a facet of a land market, which is said to be illegal in the country, which could result in indirect expropriations. ${ }^{25}$ The case of a company in the district of Gurue that displaced peasant families from their lands to a neighboring locality in another province, based on a very problematic community consultation and with negligible indemnities, has been emblematic of this process. The highly criticized lack of transparency in ProSAVANA's activities meant that the case of this company was associated with the program. The peasant leaders with whom I was able to talk, however, said that they understood that these were different processes, but they took the actions of the company and local governments as an example of what they fear could happen with the arrival of new stages of ProSAVANA.

One question that unfolds from this discussion is what are the technopolitical effects of considering land as a financial asset, which can be offered as a commodity in an international market, and not as a place of sociocultural reproduction, as has generally been the case for these peasants in their multiple and previously established relations with the land, seeds, medicinal plants, waters, among themselves, with their ancestors and spirits. As if in opposition to the constant movements that threaten to remove them from their land, the Macua people always say axinene arivava, "the owners are here." "The land is a donor, the hoe is a partner for the peasant," said one of the leaders of the Nampula Provincial Peasants' Union.

As representatives of the still nascent peasant movement in the province always reiterate, the DUAT of the peasant is a cashew tree, a mango tree, a cemetery, even a mosque. These are the elements that indicate that the community is living in that land, a peasant explained to me, reinforcing the consuetudinary character of the legislation, but also a temporality linked to agricultural cycles. As the Mozambican writer and biologist, Mia Couto (2011), emphasizes, Time as a circular entity is inherent to the philosophy of the African rural world. Moreover, it is a cyclical time based on the continuities learned through experiences with past harvests, which order community relations and resist the speculative calculation of capitalist accumulation (Bourdieu, 1979)26 brought about by integration with the market.

In Mozambique, reference to time is very present in everyday discourse. There is talk of the time of the settler, the time of Frelimo (period of socialism), the time of Samora (first president in postindependence). Now, with the projects that have flooded the country since the economic restructuring and the opening of the market, there seems to emerge a speculative time of development, which is entangled with another time much mentioned by my research interlocutors, the "time of war."

25 As Fairbairn (2013) analyzes, although the sale of land is illegal in Mozambique, there is in fact a land market that operastes through other channels, and it is common knowledge that in the country "the land is not sold, but it is bought." One example of these channels is the transfer of ownership of infrastructure and improvements, the sale of which is permitted under Mozambican law. Similarly, land is also "sold" when a company that owns the DUAT for the exploration of an area is in turn sold or divided among some shareholders. A third possibility indicated by Fairbairn occurs through compensation received by resettled communities, when the areas that they previously occupied are transferred for exploration by investors due to a "public interest," as provided for in the Land Law.

26 As Bourdieu (1979) described, referring to Algerian peasants as traditional communities in the face of a capitalist ethos, "[e]conomic decision is not determined here by taking into account a goal explicitly posited as a future like that established by calculation within the framework of a plan; economic action is oriented towards a 'forthcoming' that is directly grasped in experience or established by all the accumulated experiences which constitute the tradition" (p.8). 
It is a contexture made, for example, by a peasant who followed the case of the company in Gurue reported above, when explaining the changes in relations with colonial companies and the new companies that have emerged with this wave of investments and development projects in the Nacala Corridor:

What do they do: they give people money, people open the patch of land, they sow cotton, sesame. Then, the [settler's] company just comes to buy. The land belongs to the peasant. The peasant does everything he wants. That is what we peasants still do. When you make cotton, you [peasant] know that I have five hectares, ten hectares of cotton. And there are also automatically ten hectares of cute beans, because we work collectively. But these [new companies] don't want that. They want an independent area in which they produce. For us, no way. We are even seeing that it's a new war. We've had the settler's [war]. We've already had this sixteen-year thing, which was the civil war. Now this one, which we haven't named yet, but it's also a war. Yes, because being taken from where you were since... Hey, seriously... It's conflict (Peasant from Malema, a district in Nampula province).

He loses himself in time while remembering since when they have been in the region. In any case, not only in the words of the Macua people, but in the temporality of Mozambican legislation, the peasants are the owners of the land. Following the precept that the war of decolonization "liberated the land and man," as the former members of the anti-colonial liberation movement would claim. Something that seems to be in transformation with the arrival of this logic brought about by the financialization of the land and a cooperation based on the grammar of "corporate responsibility," as shown by the entanglements of the emerging temporalities involved in the development intervention presented by ProSAVANA.

Received: July 15, 2019

Approved: May 12, 2020

Translated by Philip Badiz 


\section{References}

AKRICH, Madeleine. 2014. « Como descrever os objetos técnicos? ». Boletim Campineiro de Geografia, 4(1): 161182.

BANCO MUNDIA/ IPEA. 2011. Ponte sobre o Atlântico. Brasil e África Subsaariana: parceria Sul-Sul para o crescimento. Washington e Brasília: World Bank e IPEA.

BATISTELLA, Mateus; BOLFE, Edson Luís. 2010. Paralelos: Corredor de Nacala. Brasília: Embrapa.

BIJKER, Wiebe; LAW, John (eds.). 1992. Shaping Technology, Building Society: Studies in Sociotechnical Change. Massachusetts: MIT Press.

BORRAS, Saturnino M.; FRANCO, Jennifer. 2012. « Global Land Grabbing and Trajectories of Agrarian Change: A Preliminary Analysis». Journal of Agrarian Change, 12(1): 34-59.

BOURDIEU, Pierre. 1979. Studies in Modern Capitalism. Algeria 1960. Cambridge: Cambridge University Press.

CABRAL, Lídia; SHANKLAND, Alex. 2013. "Narratives of Brazil-Africa Cooperation for Agricultural Development: New Paradigms?” China and Brazil in Africa Agriculture (CBAA) Project, WorkingPaper 51. Mimeo.

CAMANA, Ângela; ALMEIDA, Jalcione. 2019. " Da insustentabilidade do desenvolvimento: os discursos da produção de "vazios" no âmbito de um programa de cooperação internacional ». Civitas, 19(2): 391-408. . 2018. "Desenvolvimento e mononatureza: o caso do ProSAVANA em Moçambique ». In: Marta Inez Medeiros Marques et al. (orgs.). Perspectivas de Natureza: Geografia, formas de natureza e política. São Paulo: Annablume. pp. 191-208.

CESARINO, Letícia. 2017a. "Anthropology and the South-South Encounter: on "culture" in Brazil-Africa relations ». American Anthropologist, 119(2): 333-358.

. 2017b. "O "camponês" enquanto contexto: transferência de tecnologia em um projeto de cooperação sul-sul ». In: Carlos Emanuel Sautchuk (org.), Técnica e Transformação: perspectivas antropológicas. Rio de Janeiro: ABA publicações, pp. 333-341.

. 2014. « Antropologia multissituada e a questão da escala: reflexões com base no estudo da cooperação sul-sul brasileira ". Horizontes Antropológicos, 20(41): 19-50.

COUTO, Mia. 2011. E se Obama fosse Africano? Ensaios. São Paulo: Companhia das Letras.

DA SILVA, Luiz Inácio. 2003. Discurso do Presidente da República, Luiz Inácio Lula da Silva, no jantar oferecido pelo Presidente de Moçambique, Joaquim Chissano. Palácio da Ponte Vermelha Maputo, Moçambique. Mimeo.

DELGADO, Guilherme Costa. 2012. Do capital financeiro na agricultura à economia do agronegócio: mudanças cíclicas em meio século (1965-2012). Porto Alegre: Editora UFRGS.

EDELMAN, Marc; OYA, Carlos; BORRAS, Saturnino. 2013. «Global Land Grabs: historical processes, theoretical and methodological implications and current trajectories». Third World Quarterly, 34(9):15171531.

FAIRBNAIRN, Madeline. 2013. " Indirect dispossession: domestic power imbalances and foreign access to land in Mozambique ». Development and Change, 44(2):335-356.

FERGUSON, James. 2006. Global Shadows. Africa in the Neoliberal Global Order. Durham and London: Duke University Press.

. 1994. The anti-politics machine: "development", depoliticization, and bureaucratic power in Lesotho. Minneapolis: University of Minnesota Press.

FERRANDO, Tomaso. 2015. «Dr. Brasilia and Mr. Nacala: The apparent duality behind the brazilian statecapital Nexus ». Revista de Economia Política, 35(2): 343-359. 
FUNADA-CLASSEN, Saiaka. 2013. Analysis of the discourse and background of the ProSAVANA Programme in Mozambique - focusing on Japan's role. Tokyo. Available at: https://www.open.ac.uk/technology/ mozambique/sites/www.open.ac.uk.technology.mozambique/files/files/ProSavana\%2oAnalysis\%2o based\%20on\%20Japanese\%20source\%20(FUNADA2013).pdf. Accessed on: april 2015.

GARCIA, Ana; KATO, Karina. 2016. « Políticas públicas e interesses privados: uma análise a partir do Corredor de Nacala em Moçambique ». Cadernos CRH, 29(76): 69-86.

GUIMARÃES, Roberta Sampaio. 2014. A utopia da Pequena África: projetos urbanísticos, patrimônios e conflitos na Zona Portuária carioca. Rio de Janeiro: FGV.

GUPTA, Akhil. 1998. Postcolonial developments: agriculture in the making of modern India. Durhan \& London: Duke University Press.

HEREDIA, Beatriz; PALMEIRA, Moacir; LEITE, Sérgio Pereira. 2010. " Sociedade e economia do "agronegócio" no Brasil ». Revista Brasileira de Ciências Sociais, 25(74): 159-196.

HOSONO, Akio. 2012. "South-South/Triangular Cooperation and Capacity Development ». In: Hiroshi Kato (org.), Scaling Up South-South and Triangular Cooperation. Tokyo: JICA Research Institute. pp. 43-64.

LATOUR, Bruno; WOOLGAR, Steve. 1997. A Vida de Laboratório: a Produção dos Fatos Científicos. Rio de Janeiro: Relume-Dumará.

LI, Tania M. 2007. The will to improve: governmentality, development and the practice of politics. Durham and London: Duke University Press.

MARTINS, José de Souza. 1997. Fronteira: a degradação do Outro nos confins do humano. São Paulo: Editora Hucitec.

MBEMBE, Achille. 2001. On the Postcolony. Berkeley; Los Angeles: University of California Press.

McMICHAEL, Phillip. 2014. « Rethinking Land Grab Ontology ». Rural Sociology, 79(1): 34-55.

MITCHELL, Timothy. 2002. The rule of experts: Egypt, techno-politics, modernity. Berkeley \& Los Angeles, California: University of California Press.

MOÇAMBIQUE, Lei no 19/97, de 1 de Outubro - Lei de Terras. Mimeo.

MOORE, Donald. 1999. « The Crucible of Cultural Politics: Reworking "Development” in Zimbabwe's Eastern Highlands ». American Ethnologist, 26(3): 654-689.

MOSCA, João. 2012. « Porque é que a produção alimentar não é prioritária? » Observador Rural. Documento de Trabalho, n. 1, Maputo. Mimeo.

MOSCA, João; BRUNA, Natacha. 2015. « ProSAVANA: discursos, práticas e realidades ». Observador Rural.

Documento de Trabalho, Maputo: Observatório do Meio Rural, n. 31. Mimeo.

MORAIS, Isabela Nogueira de. 2014. "ProSAVANA e os riscos omitidos da produção sob contrato ". In: João

Mosca (org.), Aspectos da competitividade e transformação do sector agrário em Moçambique. Maputo: Escolar Editora, pp.63-84.

MORAWSKA VIANA, Catarina; RIBEIRO, Magda dos Santos. 2018. « Notas sobre a intersecção entre

Estado, Ciência, Capitalismo: desafios etnográficos em torno da técnica e da política ».R@U: revista de antropologia da UFSCar, 10(1): 9-24.

NOGUEIRA, Isabela; OLLINAHO, Ossi. 2013. From rhetoric to practice in south-south Development cooperation: a case study of Brazilian interventions in the Nacala Corridor Development Program. Institute of Socioeconomics. University of Geneva. Working Paper. Mimeo.

PROSAVANA-PD. 2013. Agriculture Development Master Plans in the Nacala Corridor in Mozambique. Report No. 2, Quick Impact Projects, Triangular Cooperation for Agricultural Development of the Tropical Savannah in Mozambique, MINAG. Mimeo.

RIBEIRO, Magda dos Santos. 2018. "Tecnopolítica em laboratórios da Embrapa e florestas de castanha ». R@U: revista de antropologia social dos alunos do PPGAS-UFSCar, 10(1): p. 80-104. 
SAID, Edward. Orientalism. New York: Vintage Books, 1979.

SANTOS, Clóvis C. M. 2018. " MATOPIBA: uma nova fronteira agrícola ou um reordenamento geográfico do agronegócio e dos espaços produtivos de "Cerrados"? . Cadernos do CEAS, 245: 570-600

SASSEN, Saskia. 2013. "A Land Grabs Today: feeding the disassembling of national territory ». Globalizations,10(1):25-46.

SHANKLAND, Alex; GONÇALVES, Euclides. 2016. «Imagining Agricultural Development in South-South Cooperation: The Contestation and Transformation of ProSAVANA ». World Development, 81: 35-46.

SIGAUD, Lygia. 1986. Efeitos Sociais de Grandes Projetos Hidrelétricos. Rio de Janeiro: Museu Nacional (Comunicação n. 9). Mimeo.

SMART, Teresa; HANLON, Joseph. 2014. Galinhas e Cerveja: uma receita para o crescimento. Maputo: Kapicua.

UAIENE, Rafael. 2012. " Estrutura, conduta e desempenho da agricultura familiar em Moçambique ». In: MOSCA, João (Org.). Contributos para o Debate da Agricultura e do Meio Rural. Maputo: Escolar Editora, pp. 49-67.

VAINER, Carlos Bernardo. 2008. "Conceito de "atingido": uma revisão do debate ». In: Franklin Daniel Rothman (org.), Vidas Alagadas. Conflitos Socioambientais, Licenciamento e Barragens. Viçosa: Ed. UFV. pp. 39-63.

VELHO, Otávio. 1981. Frentes de Expansão e Estrutura Agrária. Estudo do Processo de Penetração numa Área da Transmazônica. Rio de Janeiro: Zahar Editores.

WOLFORD, Wendy; NEHRING, Ryan. 2015. "Constructing parallels: Brazilian expertise and the commodification of land, labour and money in Mozambique ». Canadian Journal of Development Studies, $36(2): 208-223$.

\section{Vanessa Parreira Perin}

Federal University of Rio de Janeiro, Graduate program in Sociology and Anthropology,

Rio de Janeiro/RJ, Brazil

https://orcid.org/0000-0003-2305-0337

Email: vanessa_pperin@hotmail.com 